\title{
On the Comparison of Thermal Comfort Performances in Dutch Style Churches with Low Ventilation in Hot-Humid Tropical Region
}

\author{
Augi Sekatia $^{1}$, Erni Setyowati ${ }^{2, *}$, Gagoek Hardiman ${ }^{2}$ \\ ${ }^{1}$ Doctoral Program of Architecture and Urbanism, Universitas Diponegoro, Semarang, 50275, Indonesia \\ ${ }^{2}$ Department of Architecture, Faculty of Engineering, Universitas Diponegoro, Semarang, 50275, Indonesia
}

Received October 24, 2020; Revised November 23, 2020; Accepted December 30, 2020

\section{Cite This Paper in the following Citation Styles}

(a): [1] Augi Sekatia, Erni Setyowati, Gagoek Hardiman, "On the Comparison of Thermal Comfort Performances in Dutch Style Churches with Low Ventilation in Hot-Humid Tropical Region," Civil Engineering and Architecture, Vol. 8, No. 6, pp. 1419 - 1435, 2020. DOI: 10.13189/cea.2020.080625.

(b): Augi Sekatia, Erni Setyowati, Gagoek Hardiman (2020). On the Comparison of Thermal Comfort Performances in Dutch Style Churches with Low Ventilation in Hot-Humid Tropical Region. Civil Engineering and Architecture, 8(6), 1419 - 1435. DOI: 10.13189/cea.2020.080625.

Copyright $(2020$ by authors, all rights reserved. Authors agree that this article remains permanently open access under the terms of the Creative Commons Attribution License 4.0 International License

\begin{abstract}
Colonized by the Dutch for a hundred years, Indonesia has many Dutch-style churches in its cities. The uniqueness of the churches is that they have low ventilation in the below part of side-by-side walls to penetrate air movement in buildings. This current research was conducted on two Dutch-style churches with different heights of low ventilations on their walls. The study aimed to establish correlation modeling between the height of low ventilation and thermal comfort in buildings covering Standard Effective Temperature, Predicted Mean Vote (PMV), and Predicted Percentage Dissatisfied (PPD). The methods used were referred to the ASHRAE Standard 55-2017 and statistically analyzed by using linear regression and Anova of SPSS 24. The measurements were performed at the same three devotional times at similar multiple specified measuring points inside the churches. The results showed that the church with $40 \mathrm{~cm}$ height ventilations had $4 \%$ higher air velocity than that with 70 $\mathrm{cm}$ height ventilations. For PMV, the church with $40 \mathrm{~cm}$ height low ventilation has a 'neutral' sensation, while the one with $70 \mathrm{~cm}$ height low ventilations has 'slightly cool'. The church with $40 \mathrm{~cm}$ height low ventilation has $72 \%$ PPD lower significantly than the other.
\end{abstract}

Keywords Natural Low Ventilation, Comparative Modeling, Thermal Comfort, PMV, ASHRAE

\section{Introduction}

Nowadays, the concept of green architecture and sustainable development is no longer just an option, but it is already mandatory. Significant climate change is the basis of the concept, especially in the field of architecture and development because it is categorized as the greatest contributor to environmental damage and carbon dioxide emission[1]. The world also screams for sustainable architecture gained from increasing the environment and the building as an embryo of environment-friendly and low emission concepts[2-4]. The use of passive cooling design by optimizing natural ventilation is an alternative to achieve the green concept and improve energy efficiency in buildings, especially in Indonesia as a tropical country that has such extremely high solar radiation. Natural Ventilation as a passive design strategy has a significant advantage over other air conditioning strategies[5]. Passive design strategies, such as natural lighting, natural ventilation (NV), and solar energy harvesting, utilize ambient energy sources as a substitute for paid energy (e.g. electricity or natural gas) to create a comfortable living environment, thereby minimizing energy consumption and the use of various resources, such as materials, water, and soil[6]. Natural ventilation also solves some problems caused by mechanical ventilation systems, such as noise, maintenance, and energy consumption costs. The NV is not only used to 
maintain the air quality in the building, but also quite good for thermal comfort, especially in humid tropical climates, and most importantly can result in electricity savings[7]. Natural ventilation is a precise bioclimatic architectural strategy that can provide effective thermal comfort in humid tropical climates[8]. Furthermore, natural ventilation can make healthy indoor thermal conditions and eventually create thermal comfort with less electricity. Continuing, creating healthy indoor thermal conditions in the building is very important, not only because the occupants of the building will feel comfortable, but also the energy consumption will be saved and the sustainability concept of the building will be maintained[9]. This study has an update in terms of correlation modeling between the height of the low ventilation hole and the thermal comfort aspects covering Standard Effective Temperature (SET), Predicted Mean Vote (PMV), and Predicted Percentage Dissatisfied (PPD) which have never been observed by researchers before.

One of the architects' biggest concerns in designing buildings is to achieve thermal comfort [10]. A thermal comfort is a form of expression of a person's feelings expressing his satisfaction with the thermal conditions of the surrounding environment[11]. With the achievement of decent and optimal thermal conditions, one will feel comfortable to do activities in such kind of room. Thermal comfort can be obtained when the temperature is effective of $23^{\circ} \mathrm{C}-27^{\circ} \mathrm{C}$, the humidity of $30 \%-60 \%$, metabolism speed of 1.0-1.2, clothing $0.5-0.6$, and wind speeds of more than $0.2 \mathrm{~m} / \mathrm{s}$ [12]. Buildings that have decent thermal comfort can improve the productivity and performance of users[13,14]. To improve understanding of indoor thermal comfort is not only taking into account thermal comfort standards but also paying more attention to the thermal comfort of ventilation modes, and considering thermal adaptability from psychology and behavior point of view[15] for example the Predicted Percentage Dissatisfied (PPD) which represents discomfort in the room. Many scientists have studied PPD, but none of them have modeled a correlation between PPD and ventilation hole height, especially the low ventilation (LV) of buildings. This study has a rare scientific breakthrough by formulating a correlation model between the PPD and low ventilation height.

This research takes the object of two Dutch style-churches which are categorized as heritage buildings taking into account the local climate as a design concept. Similarly, Martinez et.al.[16] observed a historical building as an example of a building that achieves its thermal comfort and energy efficiency. In 2016, Dewiyana et al.[17] showed a heritage hotel called Penaga Hotel located in Georgetown city, Penang, Malaysia as a golden certificated hotel by Green Building Council which proved that historical buildings met aspects of green building. In the city of Semarang, there is a railway station building which was built during the Dutch colonial era: Tawang Semarang Station, where Rusyda et al.[18] in the research, they claimed that the thermal condition inside the station was not very high despite the tropical climate and hot weather of Semarang City due to the fabulous design considering the tropical climate. This result proves that colonial buildings have taken into account local climate and environmental conditions. Wastunimpuna et al.[19] in 2018 also examined a Dutch colonial building in Semarang city of Lawang Sewu of which in their research, also found that colonial buildings with NV make the room temperature more comfortable. As a humid tropical climate, Indonesia has wind conditions that are very useful to support the achievement of thermal comfort. With good and correct ventilation placement, even if only by using a passive design, the building has been able to achieve thermal comfort. Air vents that are always open to buildings with passive design strategies are normally at an altitude of about 1.00 meter from the ground floor. On the other hand, these current research objects are the historical Semarang Cathedral and Bogor Cathedral which have low ventilation height less than 1.00 meter from the ground floor. They have Dutch-style colonial designs that pay attention to the humid tropical climate in Indonesia. Some research has been conducted on the topic of natural ventilation; Gilani et al.[20] discussed how residential buildings using natural ventilation which was proven to save energy and have lower PMV than those using air conditioning. García et al.[21] argued the natural ventilation and thermal comfort in Bogotá where they proved that natural ventilation could decrease energy consumption and improve thermal comfort. Similarly, Gao et al.[22] claimed that the airspeed of naturally ventilated buildings could provide thermal comfort in the building. On the other hand, none of these studies examined the natural ventilation at the lower part of the buildings' wall and created a model of thermal comfort correlation. These studies formed the basis of this current research, but none of these studies examined the natural ventilation which is located at the bottom of the building wall, and create a model of thermal comfort modeling. This recent study explores uncommon modeling of the thermal conditions with low ventilation height positions.

Previous research had shown that these lower vents could provide significant differences in thermal conditions[23]. This is in line with the same density law regarding colder air being below while hot air will be lifted upwards because the cold air has a greater density than does the hot air. The research was conducted on the same object but used a different method of opening and closing the low ventilation hole to find out how the lower vents affected thermal conditions in the building. Low ventilation is successfully claimed in lowering the standard effective temperature of the room so that the room becomes cooler and comfortable to the occupants. Thermal sensation is always in the normal category and 
tends towards cooler. The Semarang and Bogor Cathedrals have different low ventilation heights from the groundfloor. The Bogor Cathedral has a ventilation position of $70 \mathrm{~cm}$ from the floor, while the Semarang Cathedral is at $40 \mathrm{~cm}$ above the floor. The different height of the low ventilation becomes the highlight of this study to find out which low ventilation height is more optimal to improve thermal comfort indoors. The research problem of this study is to find out how low ventilation height can affect SET, PMV, and also PPD from both Dutch-style churches. This study aims to obtain the correlation modeling between low ventilation height with SET, PMV, and PPD. By modeling the low ventilation height with thermal conditions of the Dutch style churches, this research is expected to be the basis and fine-tune standards of ASHRAE 55-2017 which have always been referenced in various research on thermal comfort in the tropics.

\section{Materials and Methods}

\subsection{Climatic Conditions}

Indonesia is an archipelagic country that crosses $0^{\circ}$ latitude, which is known as the equator. Astronomically,
Indonesia is located in $6^{\circ}$ North Latitude - $11^{\circ}$ South Latitude and $95^{\circ} \mathrm{E}$ East Longitude - $141^{\circ} \mathrm{E}$ East Longitude. It causes the entire region of Indonesia to have a humid tropical climate. Indonesia has only two seasons, dry season and rainy season, with rainfall fluctuations being evenly distributed in each season. According to the World Bank Group[24], the minimum average air temperature in Indonesia is $22.8^{\circ} \mathrm{C}$ while the maximum is $30.2^{\circ} \mathrm{C}$ (see Fig.1). The air humidity in Indonesia ranges from $61 \%$ to $95 \%$. The average monthly rainfall is 218.4 millimeters $(\mathrm{mm})$ per month. Figure 1 illustrates the average temperature and rainfall chart in Indonesia according to the World Bank group. With humid climate conditions having high rainfall and also hot air temperature conditions, every building in Indonesia should take efforts to respond to these three factors to achieve indoor thermal comfort.

Humid conditions require buildings in Indonesia to have a good air condition system to cope with humid conditions and high temperatures. Therefore, research on low ventilation in this current study is very relevant to climate conditions in Indonesia, especially optimizing the use of NV on buildings as a form of climate response and green architecture concept due to saving electricity and energy.

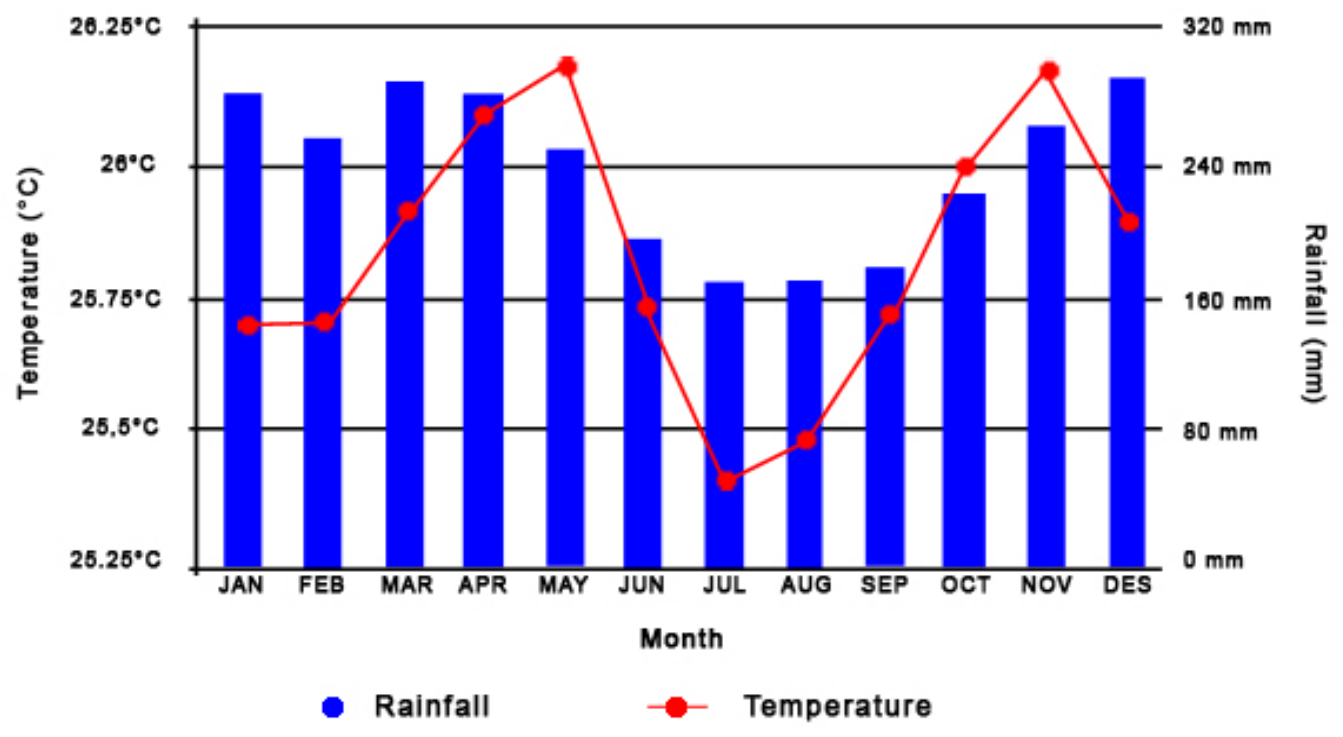

Figure 1. Average Temperature and Rainfall in Indonesia for1901-2016[24] 


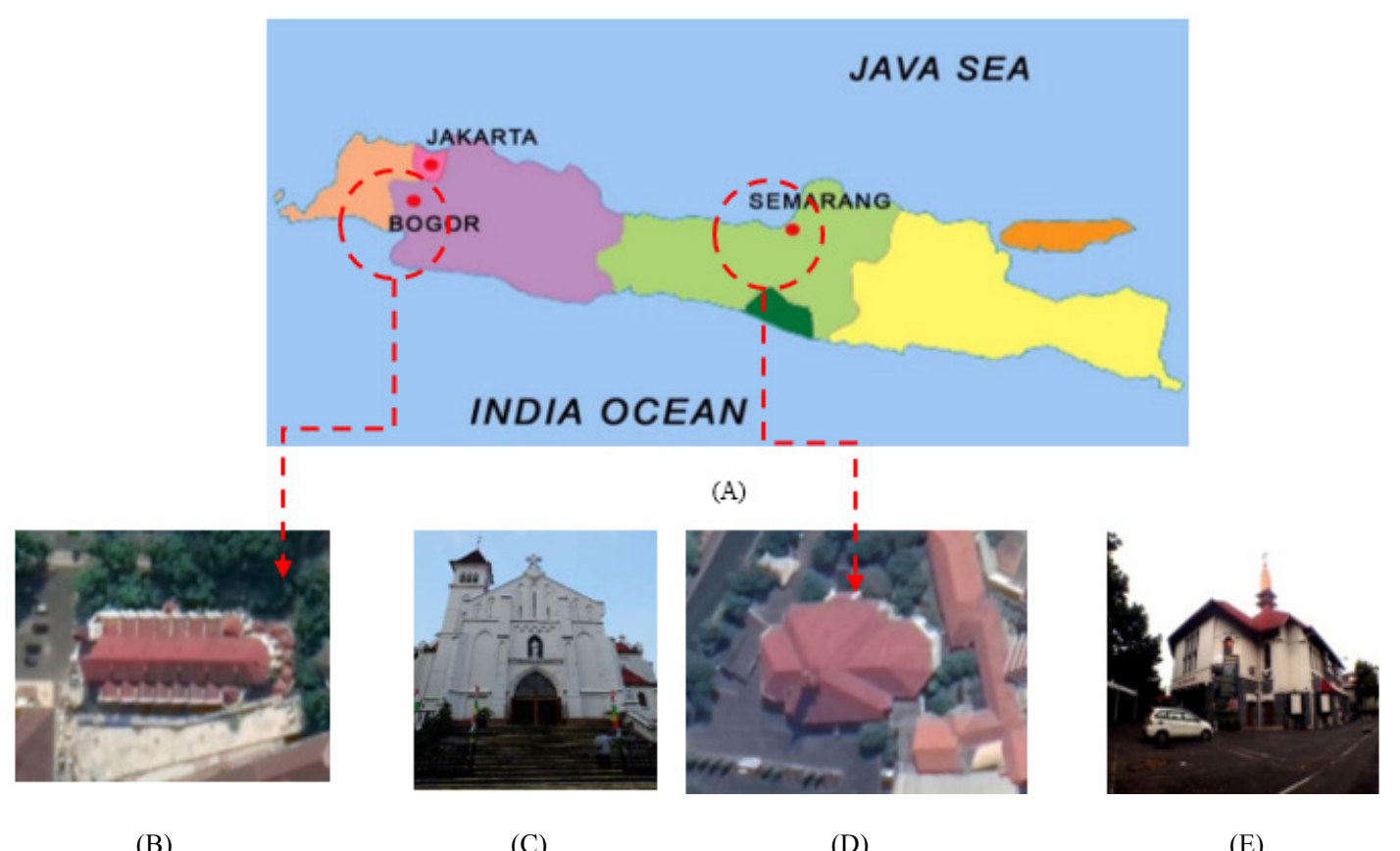

Figure 2. (A) Map of Java; (B) Site plan of Bogor Cathedral; (C) Exterior of Bogor Cathedral; (D) Semarang Cathedral Site plan; (E) Exterior of Semarang Cathedral

\subsection{Investigated Buildings}

From some of the research mentioned in the introduction section, this study looks objects from Dutch-style Churches which have low ventilation in their wall and proves that Dutch colonial buildings can respond to Indonesian climate well by optimizing the natural ventilation so far.

The research objects were taken to two Dutch colonial heritage churches: The Bogor Cathedral (Fig. 2B and 2C) and the Semarang Cathedral (see Fig. 2D and 2E). Both objects were chosen because they have ventilation in the lower part of buildings walls, while other colonial buildings do not have[23,24]. These two churches are located on Java Island in Indonesia, which has a little bit similar climatic conditions. The difference is about the geographical condition of the two buildings. The Semarang Cathedral is located in Semarang City with an altitude of $39.0 \mathrm{~m}$ above sea level[27] which can be categorized as lowland, while the Bogor Cathedral is located in Bogor City with an altitude of $190.0 \mathrm{~m}$ above sea level[28]. This difference in topography height caused a slight difference in temperature between the two buildings. Both buildings have the same orientation or direction where the longest part of the building faces north-south. The main entrance of the two churches is the same as facing westwards with the altar in the east (see Fig. 3 and 4).

\subsubsection{The Bogor Cathedral}

The Bogor Cathedral is better known as BMV (Beatae Mariae Virginis) Bogor Cathedral or The Church of The Virgin Mary as the oldest church of Catholics in Bogor (see Fig. 2B and 2C). This church is located on Kapten Muslihat street number 22 Bogor City with an area of approximately $1,248 \mathrm{~m}^{2}$. The Bogor Cathedral was built in 1896 by Pastor M.Y.D Claessens and has just been used from 1905 until now. The Church building has a direction facing the west-east, with a long side facing north-south (see Fig. 3). The entrance of the church is on the west side with the accent of a towering staircase and a statue of the Virgin Mary on it (see Fig. 2C). This church has an area of $860.50 \mathrm{~m}^{2}$ with a height in the building of $18.80 \mathrm{~m}$ then the volume of this church is $15,480 \mathrm{~m}^{3}$. 


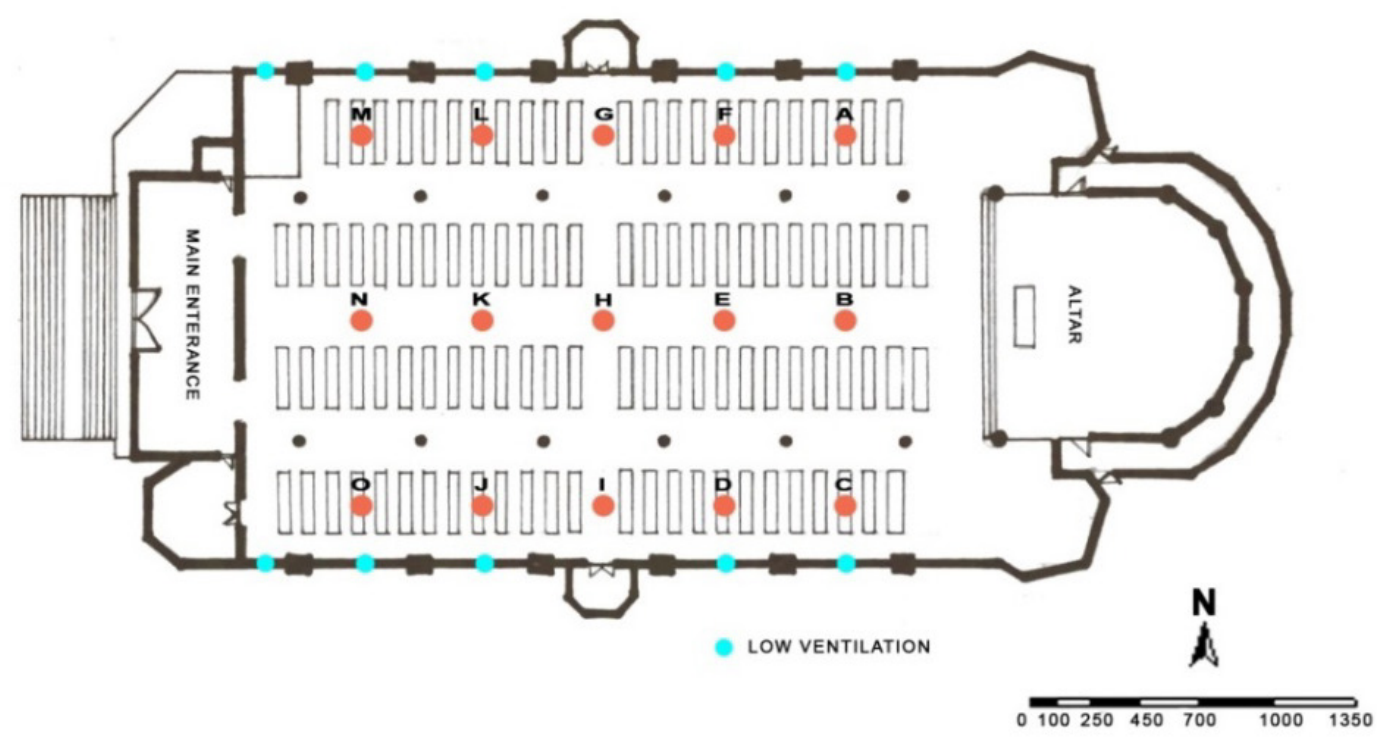

Figure 3. Bogor Cathedral Floor Plan

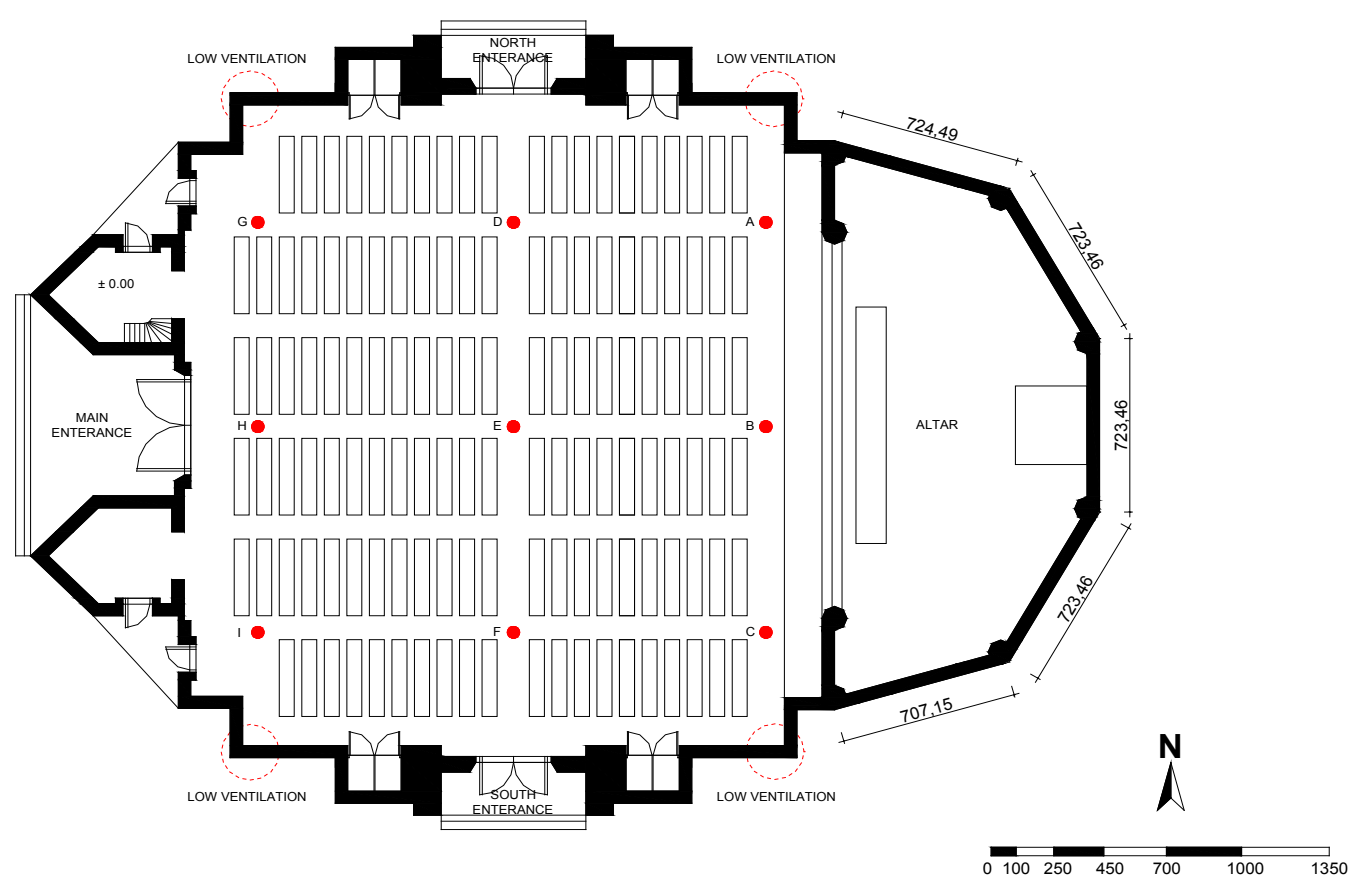

Figure 4. Semarang Cathedral Floor Plan

\subsubsection{The Semarang Cathedral}

The Semarang Cathedral (officially named as "Cathedral of The Virgin Mary queen of the Holy Rosary Randusari") is a Dutch-style church located in Pandanaran street number 9, Semarang, Central Java, Indonesia (see Fig. 2D and 2E). The cathedral is located near the landmark of Semarang city, Tugu Muda in the Randusari sub-district. The Tugu Muda area also coverings the Lawang Sewu building, Mandala Bhakti Museum, and Bulu market. The church was built and renovated by a Dutch architect named J. Th. Van Oyen was assisted by the Kleiverde constructor in 1927 then it has been used since 1928. The cathedral was built on a stone foundation, with a large, free column space in the congregation. Roofs and arches have parapets, and doors on rectangular face buildings north, west, and south; the front of the church is located to the west (see Fig. 4). The area of this Church is $890 \mathrm{~m}^{2}$ with a height of $18.50 \mathrm{~m}$ in the building; the volume of this church is $16,020 \mathrm{~m}^{3}$.

The Bogor Cathedral has a circular lower vent (see Fig. 5B) located $70 \mathrm{~cm}$ from the floor (see Fig.5D). The low ventilation elements of Bogor Cathedral (Fig. 5B and 5D) are located in the North-South orientation of the facade; the low ventilations location of this Church can be seen in 
Fig. 3 on the blue color hatching.

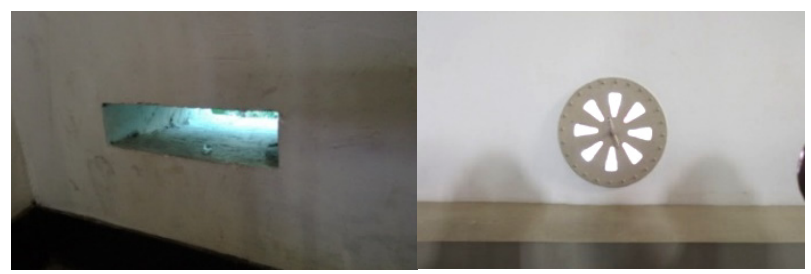

(A)

(B)

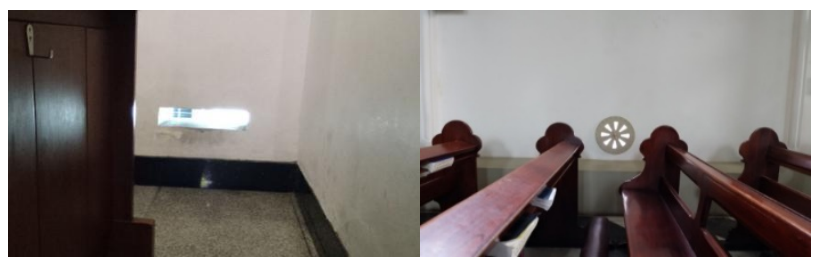

(C)

(D)

Figure 5. (A) Low Ventilation in the Semarang Cathedral; (B) Low Ventilation in the Bogor Cathedral; (C) The position of low ventilation in Semarang Cathedral from the floor; (D) The position of low ventilation in Bogor Cathedral from the floor.

Semarang Cathedral has rectangular low ventilation (see Fig. 5A), which is located at $40 \mathrm{~cm}$ high from the floor (see Fig. 5C). The locations of the low ventilations of Semarang Cathedral are indicated as red dot circles in Fig. 4 in the North-South orientation. As seen in Fig. 5A and $5 \mathrm{C}$., the low ventilations of this Church are in square shapes in the lower part of the side-by sidewall.

\subsection{Data Collections and Measurements}

Sampling data from both Dutch-style churches were taken at the same three times of worship at 8.45 a.m., 4.30 p.m., and 6.15 p.m. Data were taken during worship activities at the busiest hours. (See Table 1). At the Bogor Cathedral, measurements were carried out at 15 different points, while in the Semarang Cathedral measurements were taken at 9 different points.

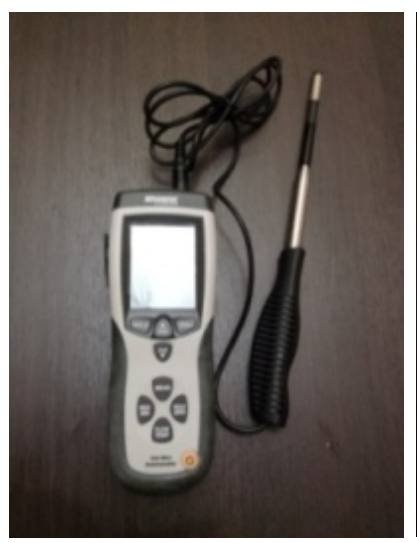

(A)

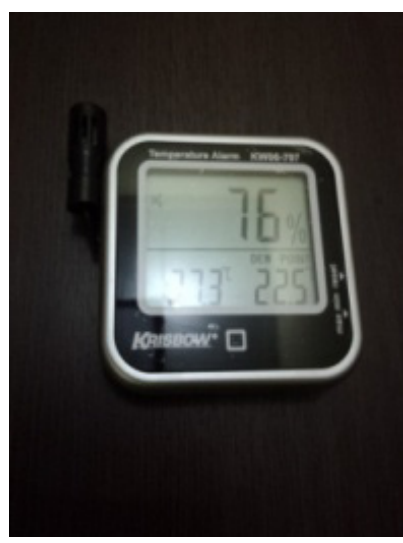

(B)
Figure 6. (A) Hotwire Anemometer ; (B) Thermo Hygrometer

The points represent the thermal state of both buildings. Data for thermal measurements inside the cathedral are relative humidity $(\%)$, airspeed $(\mathrm{m} / \mathrm{s})$, and temperature $\left({ }^{\circ} \mathrm{C}\right)$. The tools used to obtain measurement data are a hotwire anemometer (see Fig. 6A) and a digital Thermo hygrometer (see Fig. 6B). Both tools were calibrated by KAN stands for Komite Akreditasi Nasional, a national accreditation and calibration committee in Indonesia (see Table 2).

Table 1. Measuring Time

\begin{tabular}{|c|c|}
\hline Measuring Time & Period \\
\hline Morning & 8.45 a.m. \\
\hline Evening 1 & 4.30 p.m. \\
\hline Evening 2 & $6.15 \mathrm{p} . \mathrm{m}$ \\
\hline
\end{tabular}

The Krisbow Hotwire Anemometer (KW0600653) measured both air velocity and air temperature with a resolution of $0.01 \mathrm{~m} / \mathrm{s}$ and $0.1^{\circ} \mathrm{C}$ respectively. Meanwhile, the Krisbow Portable Digital Thermo Hygrometer (KW06000797) measured relative humidity with a resolution of $1 \%$ (see Table 2).

Table 2. Specifications of measurement instruments (Calibrate by KAN, certificate number S. 19012115 SNI ISO/IEC-17025-2008)

\begin{tabular}{|c|c|c|c|c|c|}
\hline Instrument & Manufacturer & Parameter & Resolution & Range & Accuracy \\
\hline \multirow{2}{*}{$\begin{array}{c}\text { Hotwire Anemometer } \\
\text { (KW0600653) }\end{array}$} & Krisbow, China & Air velocity & $0.01 \mathrm{~m} / \mathrm{s}$ & $0.1-25.0 \mathrm{~m} / \mathrm{s}$ & $\pm 5 \% \pm 0.1 \mathrm{~m} / \mathrm{s}$ \\
\cline { 3 - 6 } & Air temperature & $0.1^{\circ} \mathrm{C}$ & $0-50^{\circ} \mathrm{C}$ & $\pm 1.0^{\circ} \mathrm{C}$ \\
\hline $\begin{array}{c}\text { Portable Digital Thermo } \\
\text { Hygro meter (KW06000797) }\end{array}$ & Krisbow, China & Relative humidity & $1 \%$ & $20 \%-95 \%$ & $\pm 5 \%$ \\
\cline { 3 - 6 } & & Air temperature & $0.1^{\circ} \mathrm{C}$ & $-10-60^{\circ} \mathrm{C}$ & $\pm 1.0^{\circ} \mathrm{C}$ \\
\hline
\end{tabular}


This study used the MRT equation in its data analyses. The mean radiant temperature (MRT) is calculated in equation (1):

$$
M R T=\left[\left(T_{g}+273\right)^{4}+\frac{1.1 \times 10^{8} \times V \alpha^{0.6}}{\varepsilon D^{0.4}} T_{g}-T_{\alpha}\right]^{1 / 4}-
$$

Where $\mathrm{Tg}, \mathrm{T} \alpha, \mathrm{V} \alpha, \alpha$, and $\mathrm{D}$ represent the black-globe temperature $\left({ }^{\circ} \mathrm{C}\right)$, air temperature $\left({ }^{\circ} \mathrm{C}\right)$, air velocity at the level of the globe $(\mathrm{m} / \mathrm{s})$, emissivity, and diameter of the black globe thermometer, respectively[29]. Measurements were performed at each measuring point simultaneously. Measurement was carried out $1.10 \mathrm{~m}$ from the floor by the standard instrumentation procedure[30]. The condition of the garment was assumed to be 0.54 cloth, which means formal clothing was commonly used in mass worship. The metabolic rate was assumed to be worth 1 metabolism where this value was obtained from sitting and carrying out activities.

\subsection{Thermal Comfort Indicates}

Based on four measured environmental parameters (i.e. air temperature, Mean Radiant Temperature, relative humidity, and air velocity) and two estimated personal parameters (i.e. clothing level and metabolic rate), Predicted Mean Vote (PMV), Predicted Percentage Dissatisfied (PPD) were calculated using the CBE Thermal Comfort Tool, web-based software with ASHRAE 55-2017 standards[31]. An adaptive comfort standard such as those applied in ASHRAE 55-2017 was an alternative to PMV-based methods that allow for thermal comfort evaluation for natural - ventilated (NV) buildings.

\section{Result and Analysis}

Any comments and suggestions are welcomed so that we can constantly improve this template to satisfy all authors' research needs. Measurement and calculation results were obtained as revealed in Table 3 and Table 4. Table 3 showed that the results of field measurements as well as thermal condition calculations of the Bogor Cathedral, while Table 4 showed the results of field measurements and calculations of the thermal condition of the Semarang Cathedral. Unlike the Semarang Cathedral, the Bogor Cathedral measurements were performed at 15 measuring points (A-O, see Fig. 3) at the same time. As for the Semarang Cathedral, measurements were carried out at 9 measuring points in the building (A-I, see Fig. 4) also at the same time. Both measurements were carried out in the state of the low ventilation opened and at the time of the mass (Table 1). Tables 3 and 4 contain the results of thermal measurement of objects as well as the calculation results of SET, PMV, and PPD. The tables also contain thermal sensations felt at each measuring point calculated by the PMV calculator of the CBE Thermal Comfort Tool, web-based software with ASHRAE 55-2017 standards. Table 3 shows the data and calculations obtained from measurements at Bogor Cathedral. It can be seen that the air velocity in Bogor Cathedral tended to fluctuate at any time and every measuring point. Humidity in Bogor Cathedral ranged from $79 \%-92 \%$ and tended to decrease at 4.30 p.m. and again at 6.15 p.m. 

with Low Ventilation in Hot-Humid Tropical Region

Table 3. Thermal Condition Result at Bogor Cathedral

\begin{tabular}{|c|c|c|c|c|c|c|c|c|c|c|}
\hline Time & Spots & $\begin{array}{l}\text { MRT } \\
\left({ }^{\circ} \mathbf{C}\right)\end{array}$ & $\begin{array}{c}\text { Op. Temp } \\
\left({ }^{\circ} \mathrm{C}\right)\end{array}$ & $\begin{array}{c}\text { Temp } \\
\left({ }^{\circ} \mathrm{C}\right)\end{array}$ & RH (\%) & $\begin{array}{c}\text { airspeed } \\
(\mathrm{m} / \mathrm{s})\end{array}$ & SET $\left({ }^{\circ} \mathrm{C}\right)$ & PMV & $\begin{array}{l}\text { PPD } \\
(\%)\end{array}$ & Sense \\
\hline \multirow{15}{*}{$\begin{array}{l}8.45 \\
\text { a.m. }\end{array}$} & A & 26.50 & 27.00 & 27.50 & 85 & 0.33 & 26.20 & 0.20 & 6 & $\mathrm{n}$ \\
\hline & B & 26.70 & 27.00 & 27.30 & 86 & 0.24 & 27.00 & 0.40 & 8 & $\mathrm{n}$ \\
\hline & $\mathrm{C}$ & 25.95 & 25.90 & 25.85 & 84 & 0.39 & 24.20 & -0.30 & 7 & $\mathrm{n}$ \\
\hline & $\mathrm{D}$ & 25.70 & 25.40 & 25.10 & 84 & 0.34 & 23.80 & -0.41 & 8 & $\mathrm{n}$ \\
\hline & $\mathrm{E}$ & 26.30 & 26.60 & 26.90 & 85 & 0.22 & 26.50 & 0.29 & 7 & $\mathrm{n}$ \\
\hline & $\mathrm{F}$ & 25.35 & 24.70 & 24.05 & 85 & 0.39 & 22.70 & -0.74 & 17 & $\mathrm{sc}$ \\
\hline & G & 25.30 & 24.60 & 23.90 & 84 & 0.20 & 23.80 & -0.29 & 10 & $\mathrm{n}$ \\
\hline & $\mathrm{H}$ & 25.35 & 24.70 & 24.05 & 85 & 0.20 & 24.00 & -0.45 & 9 & $\mathrm{n}$ \\
\hline & I & 25.35 & 24.70 & 24.05 & 92 & 0.17 & 24.60 & -0.31 & 7 & $\mathrm{n}$ \\
\hline & $\mathrm{J}$ & 25.30 & 24.60 & 23.90 & 84 & 0.48 & 22.20 & -0.91 & 22 & $\mathrm{sc}$ \\
\hline & $\mathrm{K}$ & 25.20 & 24.40 & 23.60 & 87 & 0.20 & 23.60 & -0.56 & 11 & $\mathrm{sc}$ \\
\hline & $\mathrm{L}$ & 24.95 & 23.90 & 22.85 & 83 & 0.49 & 21.70 & -1.09 & 30 & $\mathrm{sc}$ \\
\hline & $\mathrm{M}$ & 25.00 & 24.00 & 23.00 & 81 & 0.53 & 21.30 & -1.24 & 37 & $\mathrm{sc}$ \\
\hline & $\mathrm{N}$ & 25.00 & 24.00 & 23.00 & 82 & 0.18 & 23.20 & -0.70 & 15 & $\mathrm{sc}$ \\
\hline & $\mathrm{O}$ & 25.00 & 24.00 & 23.00 & 78 & 0.32 & 22.10 & -0.95 & 24 & $\mathrm{sc}$ \\
\hline \multirow{15}{*}{$\begin{array}{l}4.30 \\
\text { p.m. }\end{array}$} & A & 26.25 & 26.20 & 26.15 & 83 & 0.36 & 24.70 & -0.16 & 6 & $\mathrm{n}$ \\
\hline & B & 26.35 & 26.40 & 26.45 & 82 & 0.22 & 26.10 & 0.19 & 6 & $\mathrm{n}$ \\
\hline & $\mathrm{C}$ & 26.00 & 25.70 & 25.4 & 82 & 0.43 & 23.60 & -0.44 & 9 & $\mathrm{n}$ \\
\hline & $\mathrm{D}$ & 25.55 & 24.80 & 24.05 & 83 & 0.47 & 22.40 & -0.83 & 19 & $\mathrm{sc}$ \\
\hline & $\mathrm{E}$ & 25.75 & 25.20 & 24.65 & 83 & 0.28 & 23.90 & -0.38 & 8 & $\mathrm{n}$ \\
\hline & $\mathrm{F}$ & 25.00 & 23.70 & 22.40 & 82 & 0.49 & 21.10 & -1.31 & 41 & $\mathrm{sc}$ \\
\hline & $\mathrm{G}$ & 24.80 & 23.30 & 21.80 & 81 & 0.24 & 21.90 & -1.02 & 27 & $\mathrm{sc}$ \\
\hline & $\mathrm{H}$ & 24.80 & 23.30 & 21.80 & 84 & 0.28 & 21.70 & -1.10 & 30 & $\mathrm{sc}$ \\
\hline & $\mathrm{I}$ & 24.85 & 23.40 & 21.95 & 80 & 0.31 & 21.60 & -1.15 & 33 & $\mathrm{sc}$ \\
\hline & $\mathrm{J}$ & 24.80 & 23.30 & 21.80 & 79 & 0.46 & 20.70 & -1.46 & 49 & $\mathrm{sc}$ \\
\hline & $\mathrm{K}$ & 24.90 & 23.50 & 22.10 & 80 & 0.26 & 22.00 & -1.00 & 26 & $\mathrm{sc}$ \\
\hline & $\mathrm{L}$ & 24.85 & 23.40 & 21.95 & 79 & 0.43 & 21.00 & -1.38 & 44 & $\mathrm{sc}$ \\
\hline & $M$ & 24.80 & 23.30 & 21.80 & 78 & 0.47 & 20.70 & -1.49 & 50 & $\mathrm{sc}$ \\
\hline & $\mathrm{N}$ & 24.90 & 23.50 & 22.10 & 79 & 0.19 & 22.50 & -0.96 & 24 & $\mathrm{sc}$ \\
\hline & $\mathrm{O}$ & 24.80 & 23.30 & 21.80 & 79 & 0.43 & 20.80 & -1.42 & 21.4 & $\mathrm{sc}$ \\
\hline \multirow{15}{*}{$\begin{array}{l}6.15 \\
\text { p.m. }\end{array}$} & $\mathrm{A}$ & 25.50 & 26.00 & 26.50 & 86 & 0.49 & 23.90 & -0.37 & 8 & $\mathrm{n}$ \\
\hline & $\mathrm{B}$ & 25.50 & 26.00 & 26.50 & 87 & 0.23 & 25.60 & 0.06 & 5 & $\mathrm{n}$ \\
\hline & $\mathrm{C}$ & 25.20 & 25.40 & 25.60 & 85 & 0.36 & 23.70 & -0.43 & 9 & $\mathrm{n}$ \\
\hline & $\mathrm{D}$ & 24.80 & 24.60 & 24.40 & 87 & 0.38 & 22.60 & -0.75 & 17 & $\mathrm{sc}$ \\
\hline & $\mathrm{E}$ & 24.95 & 24.90 & 24.85 & 85 & 0.30 & 23.30 & -0.51 & 10 & $\mathrm{sc}$ \\
\hline & $\mathrm{F}$ & 24.65 & 24.30 & 23.95 & 85 & 0.43 & 22.10 & -0.95 & 24 & $\mathrm{sc}$ \\
\hline & $\mathrm{G}$ & 24.85 & 24.70 & 24.55 & 87 & 0.25 & 23.50 & -0.46 & 9 & $\mathrm{n}$ \\
\hline & $\mathrm{H}$ & 24.90 & 24.80 & 24.70 & 88 & 0.23 & 23.90 & -0.37 & 8 & $\mathrm{n}$ \\
\hline & I & 24.80 & 24.60 & 24.40 & 87 & 0.27 & 23.20 & -0.55 & 11 & $\mathrm{sc}$ \\
\hline & $\mathrm{J}$ & 24.15 & 23.30 & 22.45 & 87 & 0.40 & 21.10 & -1.31 & 41 & $\mathrm{sc}$ \\
\hline & K & 24.20 & 23.40 & 22.60 & 86 & 0.32 & 21.60 & -1.31 & 32 & $\mathrm{sc}$ \\
\hline & $\mathrm{L}$ & 24.10 & 23.20 & 22.30 & 84 & 0.39 & 21.00 & -1.36 & 43 & $\mathrm{sc}$ \\
\hline & $\mathrm{M}$ & 23.65 & 22.30 & 20.95 & 85 & 0.40 & 19.90 & -1.74 & 64 & $\mathrm{c}$ \\
\hline & $\mathrm{N}$ & 23.80 & 22.60 & 21.40 & 84 & 0.31 & 20.70 & -1.45 & 48 & $\mathrm{sc}$ \\
\hline & $\mathrm{O}$ & 23.50 & 22.00 & 20.50 & 85 & 0.36 & 19.80 & -1.79 & 67 & $\mathrm{c}$ \\
\hline \multicolumn{2}{|c|}{ Average } & 25.11 & 24.44 & 23.77 & 84 & 0.34 & 23.00 & -0.8 & 22.4 & $\mathrm{sc}$ \\
\hline
\end{tabular}


For the highest SET occurred at 8.45 a.m. and the lowest was at 6.15 p.m. It shows that the more the night, the SET at Bogor Cathedral was getting lower. The PMV at Bogor Cathedral varies from 'neutral' (n) to 'slightly cool' (sc) but tended towards 'slightly cool' (sc). The average graph of air velocity, RH, SET, PMV, and PPD can be seen in Fig. 7, Fig.8, Fig. 10, Fig. 11, and Fig. 12.

Table 4 shows data and calculations obtained from measurements at the Semarang Cathedral. It can be seen that the air velocity in the Semarang Cathedral tended to rise so that the more the night, the higher the air speed on Semarang Cathedral. This affects the humidity in
Semarang Cathedral so that the more the night, the lower the humidity. The relative humidity in the Semarang Cathedral ranged from $72 \%-85 \%$. For the highest SET occurred at 6.15 p.m. and the lowest was at 8.45 a.m. This condition indicates that the later time of the day, the higher the SET at Semarang Cathedral. The PMV at the Semarang Cathedral was always on the thermal sensation of 'neutral' (n) at all times at measured point. To facilitate the analysis of data from Tables 3 and 4, an average graph of measurement and calculation results can be seen in Fig. 7, Fig. 8, Fig. 10, Fig. 11, and Fig. 12.

Table 4. Thermal Condition Result at Semarang Cathedral

\begin{tabular}{|c|c|c|c|c|c|c|c|c|c|c|}
\hline Time & Spots & $\begin{array}{c}\text { MRT } \\
\left({ }^{\circ} \mathrm{C}\right) \\
\end{array}$ & $\begin{array}{c}\text { Op. Temp } \\
\left({ }^{\circ} \mathrm{C}\right)\end{array}$ & $\begin{array}{l}\text { Temp } \\
\left({ }^{\circ} \mathrm{C}\right)\end{array}$ & RH (\%) & $\begin{array}{c}\text { airspeed } \\
(\mathrm{m} / \mathrm{s})\end{array}$ & SET $\left({ }^{\circ} \mathbf{C}\right)$ & PMV & $\begin{array}{l}\text { PPD } \\
(\%)\end{array}$ & Sense \\
\hline \multirow{9}{*}{$\begin{array}{l}8.45 \\
\text { a.m. }\end{array}$} & A & 25.20 & 25.60 & 26.00 & 82 & 0.31 & 24.20 & -0.30 & 7 & $\mathrm{n}$ \\
\hline & B & 25.40 & 25.70 & 26.00 & 83 & 0.18 & 25.60 & -0.01 & 5 & $\mathrm{n}$ \\
\hline & $\mathrm{C}$ & 25.10 & 25.60 & 26.10 & 83 & 0.26 & 24.60 & -0.20 & 6 & $\mathrm{n}$ \\
\hline & $\mathrm{D}$ & 25.90 & 26.00 & 26.10 & 84 & 0.12 & 26.80 & 0.29 & 7 & $\mathrm{n}$ \\
\hline & E & 25.80 & 25.90 & 26.00 & 85 & 0.11 & 26.50 & 0.25 & 6 & $\mathrm{n}$ \\
\hline & $\mathrm{F}$ & 25.60 & 25.80 & 26.00 & 83 & 0.18 & 25.70 & 0.03 & 5 & $\mathrm{n}$ \\
\hline & G & 25.30 & 25.70 & 26.10 & 82 & 0.24 & 24.90 & -0.12 & 5 & $\mathrm{n}$ \\
\hline & $\mathrm{H}$ & 25.50 & 25.80 & 26.10 & 82 & 0.22 & 25.20 & -0.03 & 5 & $\mathrm{n}$ \\
\hline & I & 25.20 & 25.60 & 26.00 & 82 & 0.33 & 24.00 & -0.34 & 7 & $\mathrm{n}$ \\
\hline \multirow{9}{*}{$\begin{array}{l}4.30 \\
\text { p.m. }\end{array}$} & A & 26.50 & 27.00 & 27.50 & 72 & 0.51 & 24.70 & -0.17 & 6 & $\mathrm{n}$ \\
\hline & B & 26.60 & 27.10 & 27.60 & 73 & 0.25 & 26.30 & 0.28 & 7 & $\mathrm{n}$ \\
\hline & $\mathrm{C}$ & 26.40 & 27.00 & 27.60 & 74 & 0.36 & 25.40 & 0.04 & 5 & $\mathrm{n}$ \\
\hline & $\mathrm{D}$ & 26.90 & 27.20 & 27.50 & 76 & 0.33 & 26.00 & -0.18 & 6 & $\mathrm{n}$ \\
\hline & E & 26.80 & 27.20 & 27.60 & 76 & 0.29 & 26.20 & 0.26 & 6 & $\mathrm{n}$ \\
\hline & $\mathrm{F}$ & 26.60 & 27.00 & 27.40 & 73 & 0.32 & 25.60 & 0.10 & 5 & $\mathrm{n}$ \\
\hline & G & 26.50 & 27.00 & 27.50 & 73 & 0.42 & 25.10 & -005 & 5 & $\mathrm{n}$ \\
\hline & $\mathrm{H}$ & 26.60 & 27.00 & 27.40 & 75 & 0.34 & 25.60 & 0.08 & 5 & $\mathrm{n}$ \\
\hline & I & 26.30 & 26.90 & 27.50 & 77 & 0.56 & 24.60 & -0.20 & 6 & $\mathrm{n}$ \\
\hline \multirow{9}{*}{$\begin{array}{l}6.15 \\
\text { p.m. }\end{array}$} & A & 27.10 & 28.00 & 28.90 & 72 & 0.61 & 25.60 & 0.10 & 5 & $\mathrm{n}$ \\
\hline & B & 27.20 & 28.10 & 29.00 & 72 & 0.39 & 26.60 & 0.37 & 8 & $\mathrm{n}$ \\
\hline & $\mathrm{C}$ & 27.10 & 28.00 & 28.90 & 72 & 0.49 & 26.00 & 0.21 & 6 & $\mathrm{n}$ \\
\hline & $\mathrm{D}$ & 27.10 & 28.00 & 28.90 & 72 & 0.37 & 26.60 & 0.37 & 8 & $\mathrm{n}$ \\
\hline & E & 27.10 & 28.00 & 28.90 & 73 & 0.35 & 26.80 & 0.41 & 8 & $\mathrm{n}$ \\
\hline & $\mathrm{F}$ & 27.10 & 28.00 & 28.90 & 73 & 0.45 & 26.20 & 0.27 & 6 & $\mathrm{n}$ \\
\hline & G & 27.10 & 28.00 & 28.90 & 73 & 0.57 & 25.80 & 0.15 & 5 & $\mathrm{n}$ \\
\hline & $\mathrm{H}$ & 27.20 & 28.10 & 29.00 & 72 & 0.34 & 26.90 & 0.45 & 9 & $\mathrm{n}$ \\
\hline & I & 27.10 & 28.00 & 28.90 & 72 & 0.55 & 25.80 & 0.15 & 5 & $\mathrm{n}$ \\
\hline \multicolumn{2}{|c|}{ Average } & 26.38 & 26.94 & 27.49 & 76.5 & 0.35 & 25.70 & 0.082 & 6.07 & $\mathrm{n}$ \\
\hline
\end{tabular}




\subsection{Air Velocity}

Airspeed is one of the thermal comfort factors tasked with assisting in the evaporation process that can decrease the temperature[23]. Related to this statement, Szokolay stated that the comfort zone of airspeed in tropical climates is around $0.2 \mathrm{~m} / \mathrm{s}-0.8 \mathrm{~m} / \mathrm{s}$ [32]. The measurement results then showed that the airspeed ranged at all three measuring times at the Bogor Cathedral were between $0.17 \mathrm{~m} / \mathrm{s}$ to $0.53 \mathrm{~m} / \mathrm{s}$ while in Semarang Cathedral, those results were between $0.18 \mathrm{~m} / \mathrm{s}$ to 0.61 $\mathrm{m} / \mathrm{s}$. Both the average airspeed at the Bogor Cathedral and the Semarang Cathedral was in the comfort zone for their airspeed value at all three measuring times (see Fig. 7). Therefore, it can be noted that the airspeed conditions at both Dutch-style churches were comfortable for the tropical climate. The Semarang Cathedral had a much more significant increase in airspeed than the Bogor Cathedral did. In Fig. 7, the airspeed at Semarang Cathedral increases over time. The lowest airspeed was at 8.45 a.m. with a value of $0.217 \mathrm{~m} / \mathrm{s}$ and the highest airspeed was at 6.15 p.m. with a value of $0.457 \mathrm{~m} / \mathrm{s}$. The airspeed at Bogor Cathedral did not show fluctuating values and tended to be the same.

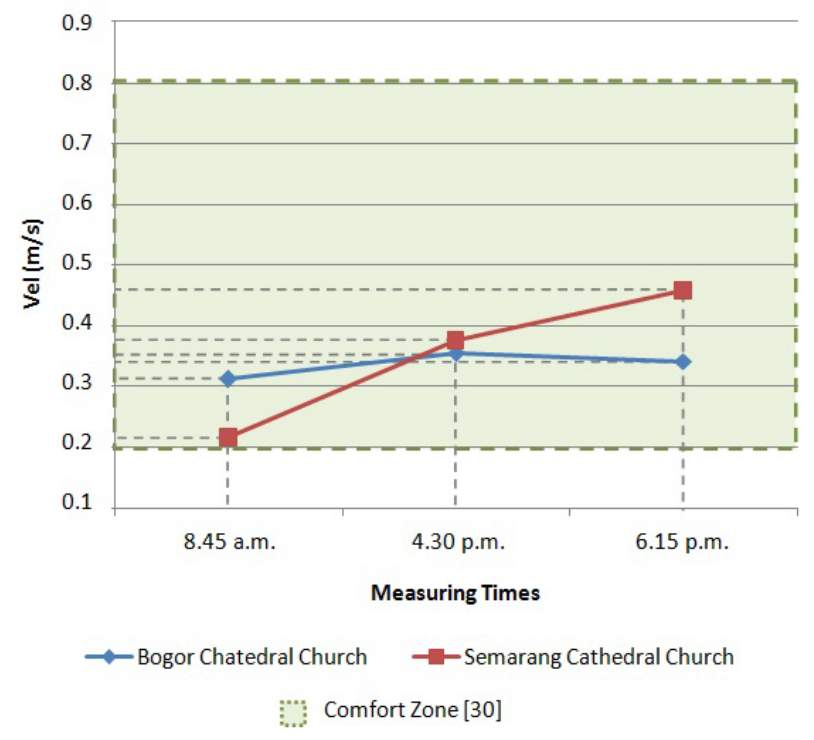

Figure 7. Average Air velocity

From the three measuring times, the range of air velocity was between $0.30 \mathrm{~m} / \mathrm{s}$ to $0.35 \mathrm{~m} / \mathrm{s}$, the difference was only $0.05 \mathrm{~m} / \mathrm{s}$. The minimum air speed was at 8.45 a.m. with a value of $0.312 \mathrm{~m} / \mathrm{s}$ while the maximum was $6.15 \mathrm{p} . \mathrm{m}$. with a value of $0.341 \mathrm{~m} / \mathrm{s}$. When compared to the volume of buildings, Bogor Cathedral has a ratio of $15,480 / 0.34$ of which 0.34 is the average airspeed in the building (see Table 3 on average). On the other hand, Semarang Cathedral has a ratio of $16,020 / 0.35$. Thus, the Semarang Cathedral has a larger volume than the Bogor Cathedral, but the Bogor Cathedral has a higher airspeed than the Bogor Cathedral. This condition occurred because the low ventilation height in Semarang Cathedral is lower than that of the Bogor Cathedral, so that the airflow into the building is higher because if it gets lower, then the air pressure will be much higher.

\subsection{Relative Humidity}

By ASHRAE Standard 55-2017[12], the relative humidity will be classified as comfortable and acceptable to humans if it is about $30 \%-90 \%$. The measurement results showed that the air humidity in the three measuring times for Bogor Cathedral were ranging from $78 \%$ to $92 \%$ while in the Semarang Cathedral; they were ranging from $72 \%$ to $85 \%$. From the measurement of the field obtained, it was indicated that the average relative air humidity of both churches was within the comfort zone (see Fig. 8).

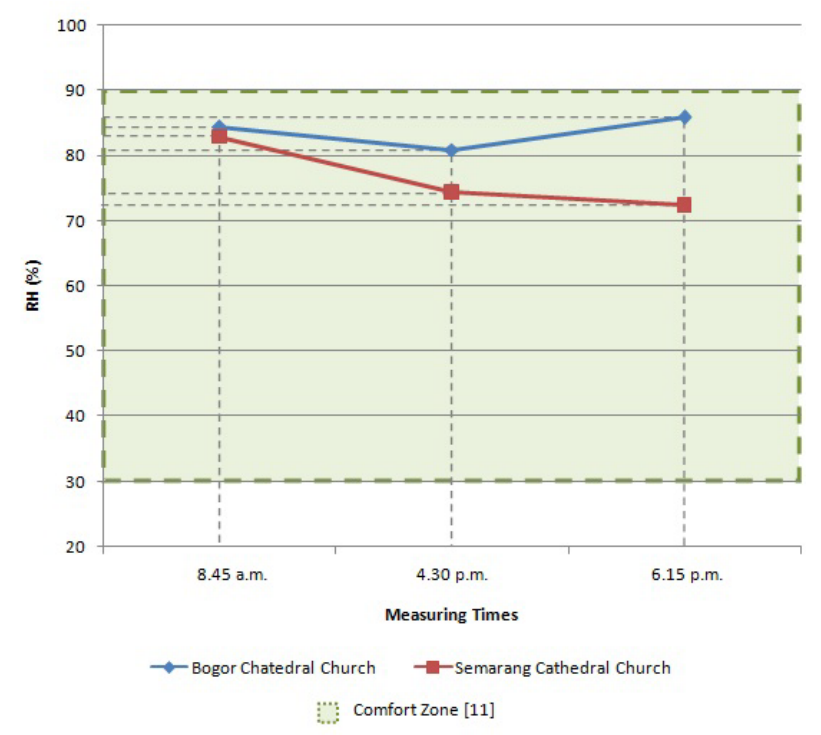

Figure 8. The Average Relative Humidity (RH)

Fig. 8 reveals that people who do activities in both churches will feel comfortable. The Relative Humidity (RH) in both churches tended to be high because it was influenced by Indonesia's hot and humid climate so the content of water points in the air tended to be fraught. It can be seen from the graph that the Bogor Cathedral had a volatile RH average with the lowest $\mathrm{RH}$ average was at 4.30 p.m. in about $80.93 \%$, while the highest was at 6.15 p.m. with $85.86 \%$. Thus, the average RH value in Bogor Cathedral has a difference of $5.03 \%$. The Semarang Cathedral had a lower RH average than Bogor Cathedral with a downward trend over time. Semarang Cathedral's lowest RH average was at 6.15 p.m. with $72.33 \%$ and the highest RH was at 8.45 a.m. with $82.89 \%$. If the volume and RH are compared between the two buildings, Bogor cathedral has a comparison of 15,480/84 (see the average humidity in Table 3), while Semarang Cathedral has a ratio of 16,020/77 (see the average humidity in Table 4). By this term, the volume of Semarang Cathedral is larger but has lower humidity than Bogor Cathedral. These 
conditions occurred due to the low ventilation position of Semarang Cathedral, which is lower to incorporate higher airspeed because by the faster airflow in the room, the water points in the air are also reduced.

\subsection{Standard Effective Temperature (SET)}

By ASHRAE Standard 55-2017[12], SET is the temperature of an imaginary environment at $50 \% \mathrm{RH}$, $<0.1 \mathrm{~m} / \mathrm{s}$ (20 fpm) in average air speed, in which the total heat loss from the skin of an imaginary occupant with an activity level of 1.0 met and a clothing level of 0.6 cloth which is the same as that from a person in the actual environment with actual clothing and activity level. The SET is a method of calculating thermal conditions despite of using PMV and PPD parameters. Fig. 9 describes a comfort zone of SET, while from Table 3 and Table 4, Bogor Cathedral and the Semarang Cathedral have SET value of about $19.8^{\circ} \mathrm{C}$ to $26.5^{\circ} \mathrm{C}$ and $24^{\circ} \mathrm{C}$ to $26.9^{\circ} \mathrm{C}$ respectively. Fig. 10 shows the average SET of Bogor Cathedral was at 8.45 a.m. with $23.79^{\circ} \mathrm{C}$ and the lowest occurred at 4.30 p.m. with a value of $22.31^{\circ} \mathrm{C}$. There was no noticeable difference in the fluctuations in the average value of SET at Bogor Cathedral, and the difference between the highest and the lowest SET was only $1.48^{\circ} \mathrm{C}$. The Semarang Cathedral has SET average values that rise over time, but the increment of SET was not very significant with the difference between the highest and lowest average values being only $0.98^{\circ} \mathrm{C}$.

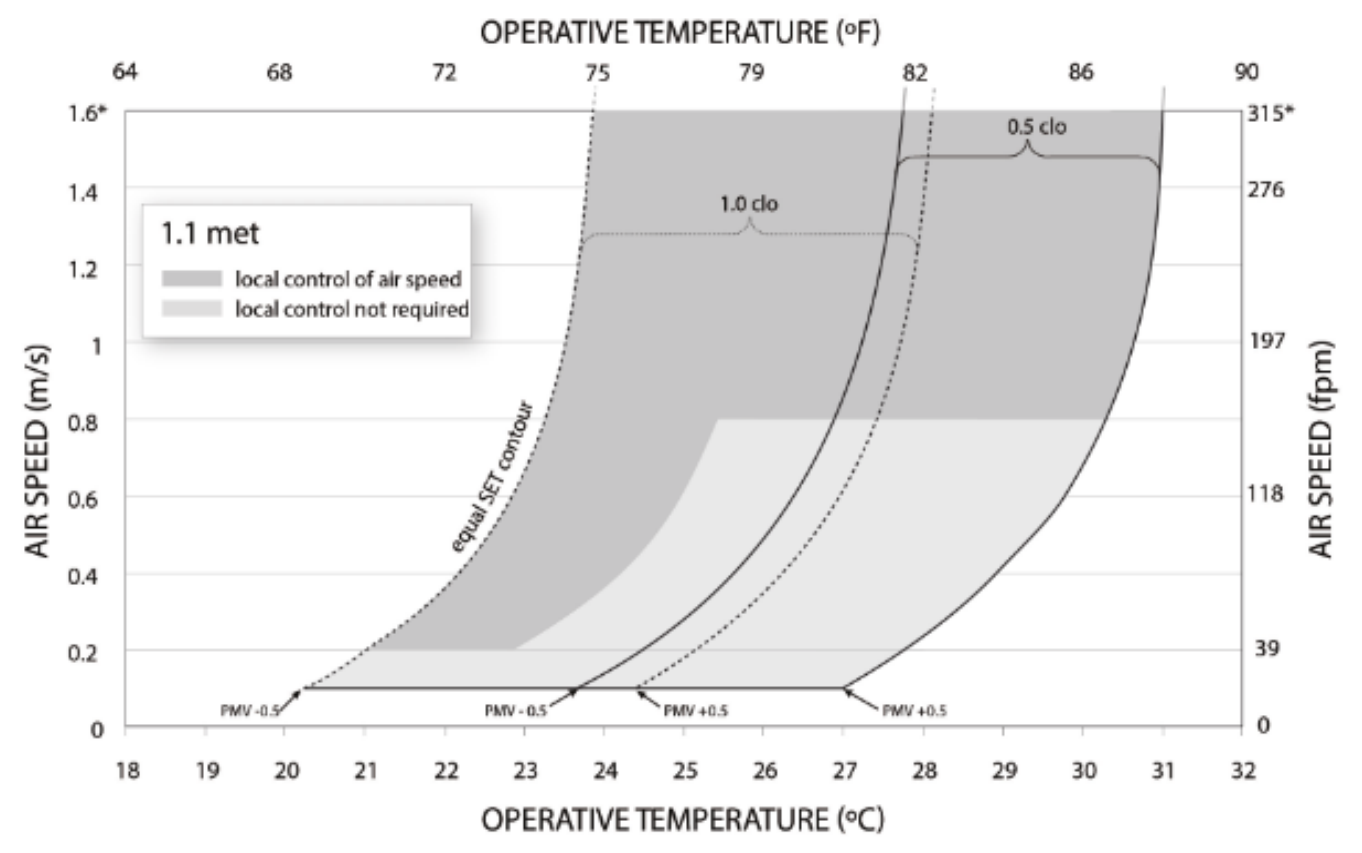

Figure 9. Comfort Zone of SET[12] 


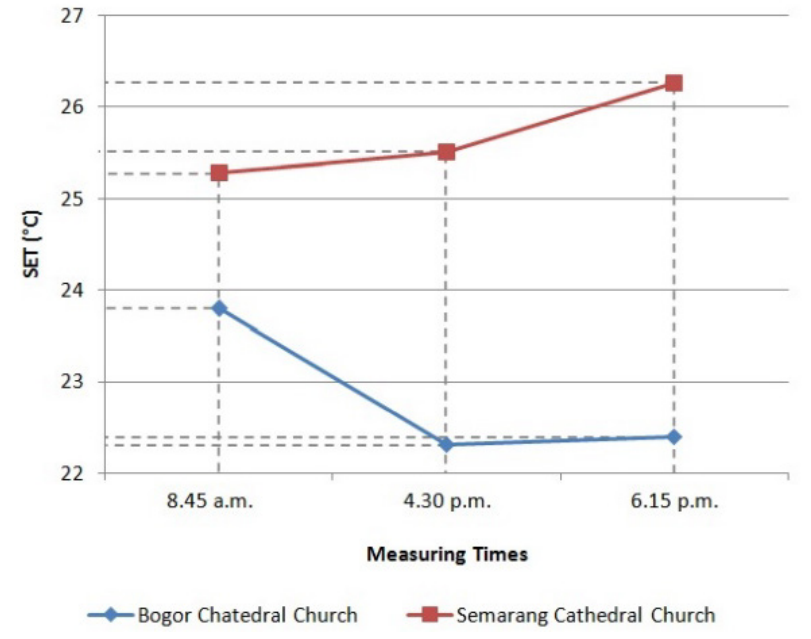

Figure 10. SET Average

The average SET of Semarang Cathedral was $25.27^{\circ} \mathrm{C}$ at $8.45 \mathrm{a} . \mathrm{m}$. while the highest at $6.15 \mathrm{p} . \mathrm{m}$. with $26.25^{\circ} \mathrm{C}$. The average SET chart in Figure 10 all goes into the comfort zone. It can be concluded that the entire average value of SET in both buildings at each measuring point was categorized as a comfort zone even though the Bogor Cathedral has a lower SET condition than the Semarang Cathedral. This was due to the difference in the geographical conditions of the two buildings. The volume and SET comparisons of the two buildings showed no significant differences.

\subsection{PMV (Predicted Mean Vote)}

The ASHRAE 55-2017 states that PMV (Predicted Mean Vote) is an index that predicts the mean value of the thermal sensation votes (self-reported perceptions) of a large group of persons on a sensation scale expressed from -3 to +3 corresponding to the categories "cold," "cool," "slightly cool," "neutral," "slightly warm," "warm," and "hot" [12]. This method is the most commonly used method for predicting thermal sensations in a building. In Table 3 felt of visitors inside Bogor Cathedral ranged from neutral, slightly cool, and cool, while for Semarang Cathedral in Table 4 shows a neutral thermal sensation at each measuring point and measuring time.

The average PMV value in both buildings in Fig. 11 shows a stark difference where the average PMV value for Semarang Cathedral was always above 0 except at 8.45 a.m. The measurement at 8.45 a.m. had an average PMV value of -0.047 , while at 4.30 p.m., the PMV had a value of 0.017 , and at 6.15 p.m. had a value of 0.27 . However, for its thermal sensations, everything tended into a neutral thermal sensation.

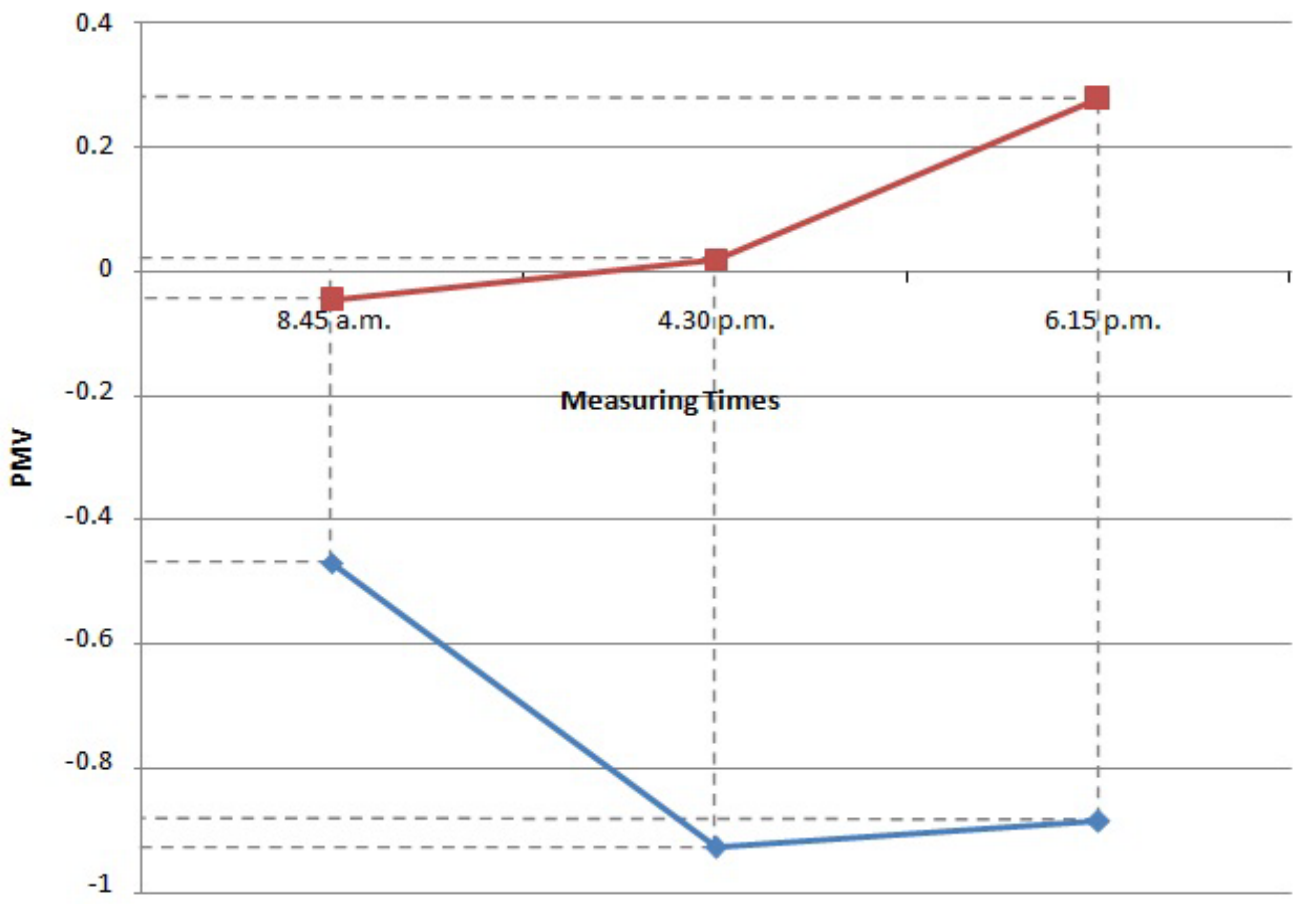

$\rightarrow$ Bogor Chatedral Church $\rightarrow-$ Semarang Cathedral Church

Figure 11. PMV Average 
For Bogor Cathedral, the neutral thermal sensation was only available at 8.45 a.m. with a value of -0.47 . At other times, the perceived thermal was slightly cool at 4.30 p.m. with a value of -0.93 , and at 6.15 p.m. with a value of -0.88. The PMV values did not show comfort or uncomfortable zones. The PMV value only shows the thermal sensation felt by visitors to such kind of place.

\subsection{PPD (Predicted Percentage Dissatisfied)}

The ASHRAE 55-2017 states that PPD (Predicted Percentage Dissatisfied) is an index that establishes a quantitative prediction of the percentage of thermally dissatisfied people determined from PMV[12]. The value of PPD shows how many people feel uncomfortable based on PPD calculations. However, from previous research PPD scores have little effect with TSV (Thermal Sensation Vote) because most respondents especially in the tropics tend to adapt to thermal conditions and have a very high threshold of discomfort[25].

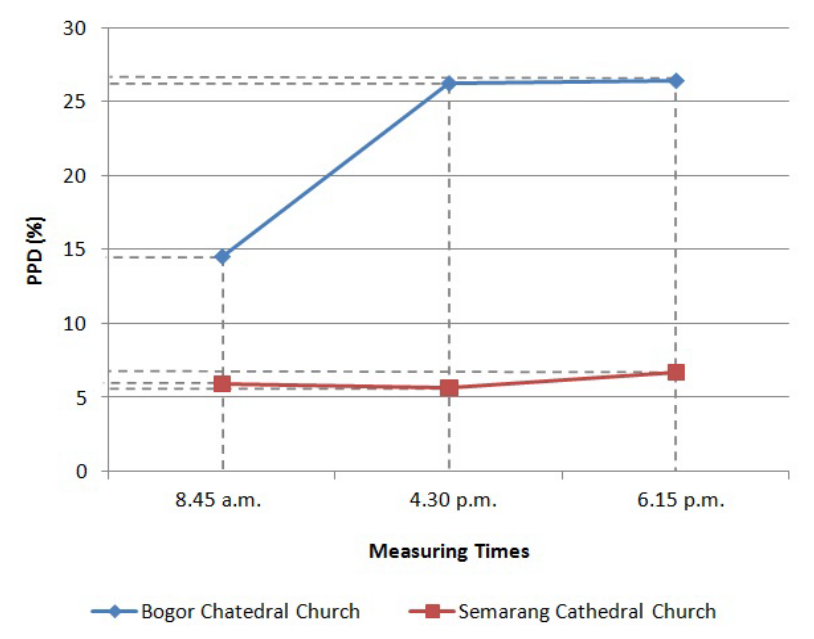

Figure 12. PPD Average

Table 3 shows the PPD value in Bogor Cathedral which has interesting PPD fluctuations because in this church there are three thermal sensations covering: 'neutral', 'slightly cool', and 'cool'. The result was also influenced by the geographical condition of Bogor city, which is located in the highlands. The PPD values at Bogor Cathedral ranged from $5 \%$ to $67 \%$. The percentage of dissatisfaction of respondents was high due to the perceived thermal sensation towards 'cool'. Meanwhile, Table 4 shows the PPD value at Semarang Cathedral whose value has not changed much because the thermal sensation is only in the 'neutral' rating. The PPD value of Semarang Cathedral ranged from $5 \%$ to $9 \%$, which means that respondents who were dissatisfied with thermal sensation tended to be low on only 5-9\%. For easy analysis, the average graph of PPD in both buildings can be seen in Fig. 12. The average PPD value at Semarang Cathedral had the least changed value, ranging only from $5.67 \%$ to $6.67 \%$. While in the Bogor Cathedral, the average value of PPD ranged from $14.53 \%$ to $26.4 \%$ with the highest score was at 6.15 p.m.

\subsection{Regression Model}

From the above data and discussion, it can be concluded that the low ventilation height affects SET, PMV, and PPD. To get equations from these three variables, the statistical analyses test was applied to the data listed in Tables 3 and 4. The analyses help to get an equation or modeling between the low ventilation heigh and SET, PMV, and PPD respectively.

\subsubsection{Regression Model with the Standard of Effective Temperature as Dependent Variable}

The first regression model demonstrated the effect of low ventilation height and air velocity on the Standard of Effective Temperature (SET).

Table 5. Model Summary Regression 1

\begin{tabular}{|c|c|c|c|c|}
\hline Model & R & $\begin{array}{c}\text { R } \\
\text { Square }\end{array}$ & $\begin{array}{c}\text { Adjusted R } \\
\text { Square }\end{array}$ & $\begin{array}{c}\text { Std. An error of the } \\
\text { Estimate }\end{array}$ \\
\hline 1 & $.738^{\mathrm{a}}$ & .544 & .531 & 1.38817 \\
\hline
\end{tabular}

a. Predictors: (Constant), Air Velocity (m/s), Low Ventilation Height $(\mathrm{H})$

In Table $5, \mathrm{R}$ is the correlation coefficient. It can be read that the correlation coefficient value between air velocity and low ventilation height against SET is 0.738 . It means that there was a strong correlation between air velocity and low ventilation height against SET at about $73.8 \%$.

$\mathrm{R}$ square is called the Determination Coefficient. From Table 5 it can be read that the value of R square (R2) is 0.544 which means that $54.4 \%$ of the variation struck against the low height of the SET is due to variations in air velocity and low ventilation height.

Table 6. Regression Model 1

(A)

\begin{tabular}{|c|c|c|c|c|c|c|}
\hline \multicolumn{2}{|c|}{ Model } & $\begin{array}{c}\text { Sum of } \\
\text { Squares }\end{array}$ & df & Mean Square & F & Sig. \\
\hline \multirow{2}{*}{1} & Regression & 158.816 & 2 & 79.408 & 41.208 & $.000^{\mathrm{b}}$ \\
\cline { 2 - 7 } & Residual & 132.964 & 69 & 1.927 & & \\
\cline { 2 - 8 } & Total & 291.780 & 71 & & & \\
\hline
\end{tabular}

a. Dependent Variable: Standard Effective Temperature $\left({ }^{\circ} \mathrm{C}\right)$

b. Predictors: (Constant), Air Velocity (m/s), Low Ventilation Height $(\mathrm{H})$

(B)

\begin{tabular}{|c|c|c|c|c|c|c|}
\hline \multicolumn{2}{|c|}{ Model } & \multicolumn{2}{|c|}{$\begin{array}{c}\text { Unstandardized } \\
\text { Coefficients }\end{array}$} & $\begin{array}{c}\text { Standardized } \\
\text { Coefficients }\end{array}$ & \multirow{2}{*}{ t } & \multirow{2}{*}{ Sig. } \\
\cline { 2 - 6 } & B & $\begin{array}{c}\text { Std. } \\
\text { Error }\end{array}$ & Beta & & \\
\hline \multirow{2}{*}{1} & \begin{tabular}{c} 
(Constant) \\
\cline { 2 - 6 }
\end{tabular} & 20.582 & .752 & & 27.373 & .000 \\
\hline & $\begin{array}{c}\text { Lentilation } \\
\text { Height (H) }\end{array}$ & .097 & .011 & .700 & 8.604 & .000 \\
\cline { 2 - 6 } & $\begin{array}{c}\text { Air Velocity } \\
\text { (m/s) }\end{array}$ & -4.856 & 1.428 & -.277 & -3.400 & .001 \\
\hline
\end{tabular}

a. Dependent Variable: Standard of Effective Temperature $\left({ }^{\circ} \mathrm{C}\right)$ 
It can be said that the height of the low ventilation and the air velocity simultaneously affect the SET because it can be seen in Table 6A sig value of $<0.05$. In Table $6 \mathrm{~B}$, the constant value is 20.582 which means without any influence from the height of the low ventilation and air velocity, the local SET starts at $20.582^{\circ} \mathrm{C}$. The regression coefficient of Low ventilation height of 0.097 which is defined when the low ventilation height is $1 \mathrm{~cm}$ will increase the SET by $0.097^{\circ} \mathrm{C}$. The air velocity regression coefficient of -4.856 is defined when the airspeed is $1 \mathrm{~m} / \mathrm{s}$ it will reduce the SET by $4.856^{\circ} \mathrm{C}$. After regressing the variable height of the low ventilation, air velocity, and SET on Table 6B then it is obtained the equation model (2):

$$
S E T=20.582+0.097 H-4.856 \text { VEL }
$$

Where SET is Standard of Effective Temperature $\left({ }^{\circ} \mathrm{C}\right)$, $\mathrm{H}$ is the low ventilation height of the floor (m), and $\mathrm{Vel}$ is air velocity $(\mathrm{m} / \mathrm{s})$. This equation means that every $1^{\circ} \mathrm{C}$ decrease, in the Standard of Effective Temperature, will be achieved if the low ventilation height decreases by $0.097 \mathrm{~m}$ and the air velocity increases by $4.856 \mathrm{~m} / \mathrm{s}$.

\subsubsection{Regression Model with Predicted Mean Vote Dependent Variable}

The second regression model shows the effect of low ventilation height and Standard Effective temperature on PMV.

Table 7. Model Summary Regression 2

\begin{tabular}{|c|c|c|c|c|}
\hline Model & $\mathbf{R}$ & $\begin{array}{c}\mathbf{R} \\
\text { Square }\end{array}$ & $\begin{array}{c}\text { Adjusted R } \\
\text { Square }\end{array}$ & $\begin{array}{c}\text { Std. An error of the } \\
\text { Estimate }\end{array}$ \\
\hline 1 & $.992^{\mathrm{a}}$ & .984 & .984 & .07807 \\
\hline
\end{tabular}

a. Predictors: (Constant), Standard Effective Temperature $\left({ }^{\circ} \mathrm{C}\right)$, Low Ventilation Height $(\mathrm{H})$

In Table 7, the correlation coefficient value between SET and low ventilation height against PMV is 0.992. It means that the relationship between SET and low ventilation height to PMV is $99.2 \%$. It can be read that the value of $R$ square $\left(R^{2}\right)$ is 0.984 , and it means that $98.4 \%$ variation that occurs against the low height of PMV due to the variation of SET and low ventilation height. It means that PMV is influenced by the height of LV and the SET (see Table 7).

Table 8. Regression Model 2

(A)

\begin{tabular}{|c|c|c|c|c|c|c|}
\hline & Model & $\begin{array}{l}\text { Sum of } \\
\text { Squares }\end{array}$ & df & Mean Square & $\mathbf{F}$ & Sig. \\
\hline & Regression & 26.427 & 2 & 13.214 & 2167.807 & $.000^{\mathrm{b}}$ \\
\hline \multirow[t]{2}{*}{1} & Residual & .421 & 69 & .006 & & \\
\hline & Total & 26.848 & 71 & & & \\
\hline
\end{tabular}

a. Dependent Variable: Predicted Mean Vote

b. Predictors: (Constant), Standard of Effective Temperature $\left({ }^{\circ} \mathrm{C}\right)$, Low Ventilation Height $(\mathrm{H})$
(B)

\begin{tabular}{|c|c|c|c|c|c|c|}
\hline \multirow{2}{*}{\multicolumn{2}{|c|}{ Model }} & \multicolumn{2}{|c|}{$\begin{array}{c}\text { Unstandardized } \\
\text { Coefficients }\end{array}$} & \multirow{2}{*}{$\begin{array}{c}\begin{array}{c}\text { Standardized } \\
\text { Coefficients }\end{array} \\
\text { Beta }\end{array}$} & \multirow{2}{*}{ t } & \multirow{2}{*}{ Sig. } \\
\hline & & B & $\begin{array}{l}\text { Std. } \\
\text { Error }\end{array}$ & & & \\
\hline \multirow{3}{*}{1} & (Constant) & -7.691 & .124 & & -62.026 & .000 \\
\hline & $\begin{array}{c}\text { Low Ventilation } \\
\text { Height }(\mathrm{H})\end{array}$ & -.001 & .001 & -.019 & -.921 & .360 \\
\hline & SET $\left({ }^{\circ} \mathrm{C}\right)$ & .305 & .006 & 1.005 & 48.655 & .000 \\
\hline
\end{tabular}

a. Dependent Variable: Predicted Mean Vote

Table 8A. shows a significant value of $<0.05$, which indicates that the low ventilation height and SET affect the PMV value. In Table 8B, the constant value of $-7,691$ means without any influence from SET and air velocity, the PMV starts at -7.691 . The low ventilation height regression coefficient of -0.001 is defined when the low ventilation height is $1.0 \mathrm{~cm}$, it will reduce the PMV by 0.001 . The SET regression coefficient is 0.305 which can be interpreted if SET is $1{ }^{\circ} \mathrm{C}$ it will increase PMV by 0.305 .

After regressing the variable set, the low ventilation height and PMV in Table $8 \mathrm{~B}$ are obtained by the equation model (3):

$$
P M V=-7.691-0.001 H+0.305 \text { SET }
$$

Where PMV is the predicted mean vote, $\mathrm{H}$ is the low ventilation height of the floor $(\mathrm{cm})$, and the SET is standard effective temperature $\left({ }^{\circ} \mathrm{C}\right)$. The equation concludes that if you want to decrease the value of PMV, so you have to increase the height of low ventilation and decrease the SET.

\subsubsection{Regression Model with Predicted Percentage Dissatisfied Dependent Variable}

The third regression model shows the effect of low ventilation height and SET on PPD. Where SET is Standard Effective Temperature and PPD stands for the Percentage Predicted of Discomfort.

Table 9. Model Summary Regression 3

\begin{tabular}{|c|c|c|c|c|}
\hline Model & R & R Square & $\begin{array}{c}\text { Adjusted R } \\
\text { Square }\end{array}$ & $\begin{array}{c}\text { Std. An error of the } \\
\text { Estimate }\end{array}$ \\
\hline 1 & $.865^{\mathrm{a}}$ & .748 & .741 & 7.82553 \\
\hline
\end{tabular}

a. Predictors: (Constant), Standard Effective Temperature $\left({ }^{\circ} \mathrm{C}\right)$, Low Ventilation Height $(\mathrm{H})$

In Table 9, the correlation coefficient value between SET and low ventilation height against PPD is 0.865 meaning the relationship between SET and low ventilation height to PPD is $86.5 \%$. In Table 9, the value of $R$ square $\left(\mathrm{R}^{2}\right)$ is 0.748 , which means that $74.8 \%$ of the variation struck against the percentage of PPD is due to the variation in SET and low ventilation height. Therefore, it can be certainly noted that PPD is heavily influenced by the height of the low ventilation and the SET. 
Table 10. Regression Model 3

(A)

\begin{tabular}{|c|c|c|c|c|c|}
\hline Model & $\begin{array}{c}\text { Sum of } \\
\text { Squares }\end{array}$ & df & Mean Square & $\mathbf{F}$ & Sig. \\
\hline Regression & 12572.450 & 2 & 6286.225 & 102.651 & $.000^{b}$ \\
\hline 1 Residual & 4225.483 & 69 & 61.239 & & \\
\hline Total & 16797.933 & 71 & & & \\
\hline
\end{tabular}

a. Dependent Variable: Predicted Percentage Dissatisfied (\%)

b. Predictors: (Constant), Standard Effective Temperature $\left({ }^{\circ} \mathrm{C}\right)$, Low Ventilation Height $(\mathrm{H})$

(B)

\begin{tabular}{|c|c|c|c|c|c|c|}
\hline \multirow{2}{*}{\multicolumn{2}{|c|}{ Model }} & \multicolumn{2}{|c|}{$\begin{array}{c}\text { Unstandardized } \\
\text { Coefficients }\end{array}$} & \multirow{2}{*}{$\begin{array}{c}\begin{array}{c}\text { Standardized } \\
\text { Coefficients }\end{array} \\
\text { Beta }\end{array}$} & \multirow{2}{*}{$\mathbf{t}$} & \multirow{2}{*}{ Sig. } \\
\hline & & B & $\begin{array}{l}\text { Std. } \\
\text { Error }\end{array}$ & & & \\
\hline \multirow{3}{*}{1} & (Constant) & 181.520 & 12.428 & & 14.606 & .000 \\
\hline & $\begin{array}{c}\text { Low Ventilation } \\
\text { Height }(\mathrm{H})\end{array}$ & .140 & .087 & .133 & 1.612 & .111 \\
\hline & $\operatorname{SET}\left({ }^{\circ} \mathrm{C}\right)$ & -7.215 & .628 & -.951 & -11.488 & .000 \\
\hline
\end{tabular}

a. Dependent Variable: Predicted Percentage Dissatisfied (\%)

PPD is affected by low ventilation height and SET is reinforced with the significant results listed on the Table 10A. The significance in Table 10A shows a value of $<$ 0.05 , thus indicating that the low ventilation height and SET affect the PPD value. In Table 10B, the constant value is 181.52. It means that without any influence from SET and air velocity, the PPD will start at $181.52 \%$. Low ventilation height regression coefficient of 0.140 , which can be interpreted if the low ventilation height is $1.00 \mathrm{~cm}$, it will increase PPD by $0.14 \%$. SET regression coefficient of -7.215 which can be interpreted if SET is $1.0^{\circ} \mathrm{C}$ it will reduce $\mathrm{PPD}$ by 7.125 . The regression values of the low ventilation height variables, SET and PPD in Table 10B can then form a model equation (4) as follows:

$$
P P D=181.520+0.14 H-7.215 \text { SET }
$$

Where PPD is the Predicted Percentage Dissatisfied $(\%), \mathrm{H}$ is the low ventilation height of the floor $(\mathrm{cm})$, and SET is the Standard of Effective Temperature $\left({ }^{\circ} \mathrm{C}\right)$. The equation concludes that if you want to decrease PPD you have to decrease the height of low ventilation and increase the value of SET. These three equation models can further assist calculations in simulating and finding variable values of low ventilation height, air velocity, SET, PMV, and PPD.

\section{Conclusions}

From the above measurement and analyses, it can be concluded that in Bogor Cathedral with a volume of $15,480 \mathrm{~m}^{3}$, the ventilation height is below $70 \mathrm{~cm}$ from the floor, has a lower airspeed of $4 \%$ compared to Semarang Cathedral with a volume of $16,020 \mathrm{~m}^{3}$, and a ventilation height of $40 \mathrm{~cm}$ from the floor. This is due to the height of the low ventilation, where the low ventilation of the Semarang Cathedral puts more air into the building. With that high air velocity, the Semarang Cathedral has lower humidity than the Bogor Cathedral. For thermal conditions and thermal sensation, the Bogor Cathedral has thermal conditions that tend to be cooler than the Semarang Cathedral. Bogor Cathedral has an average of SET $23^{\circ} \mathrm{C}$, while the Semarang Cathedral is $26^{\circ} \mathrm{C}$. However, both results are categorized as the comfort zones refer to the ASHRAE 55-2017's comfort zone chart. The PMV and PPD from the Bogor and Semarang Cathedrals have quite significant differences. The thermal sensation at the Bogor Cathedral tends towards 'slightly cool', while Semarang Cathedral is in 'neutral' condition. This resulted in PPD in the Bogor Cathedral as being 72\% higher than the Semarang Cathedral, which means quantitatively, more respondents are dissatisfied with thermal sensations in the Bogor Cathedral although previous research has stated that the adaptive nature of respondents will always lead to comfort. Therefore, when drawn conclusions, the height of the low ventilation affects the airspeed that enters the building, and this is said to affect the addition of cooling sensation to the building. Both buildings are in their comfort zone, only Bogor Cathedral has cooler thermal conditions. For PMV and PPD quantitatively, a more recommended condition and less dissatisfaction are the situations at Semarang Cathedral. From the data of the two churches that have a difference in the height of the low ventilation then to make it easier to get a simulation of the amount of value from; low ventilation height, SET, PMV and PPD can use (2) $S E T=20.582+0.097 \mathrm{H}-4.856 \mathrm{VEL}$ (3) $\quad P M V=-7.691-0.001 \mathrm{H}+0.305 \mathrm{SET}$; (4) $P P D=181.520+0.14 \mathrm{H}-7.215$ SET.

\section{Nomenclature}

American Society of Heating,

ASHRAE Refrigerating and Air-Conditioning Engineers

ISO International Organization of Standardization

PMV Predicted Mean Vote

PPD Predicted Percentage Dissatisfied (\%)

SET Standard Effective Temperature $\left({ }^{\circ} \mathrm{C}\right)$

MRT Mean Radiant Temperature $\left({ }^{\circ} \mathrm{C}\right)$

VEL Air Velocity (m/s)

$\mathrm{H} \quad$ Ventilation height

NV Natural Ventilation

KAN Indonesian Committee of Accreditation and Calibration 


\section{Author Contributions}

Conceptualization, A.S. and E.S.; Introduction and Methodology, A.S., E.S., and G.H.; Visualization map and graphs, A.S.; Analyzing Data and Interpretation, A.S. and E.S.; Documentation and photography, A.S. and G.H.; Conclusion, A.S., and E.S.

\section{Funding}

This research has been funded by the Indonesian Ministry of Education and Culture through the Doctoral Research grant number 225-23/UN7.6.1/PP/2020 (DIKTI).

\section{Acknowledgments}

Therefore, we would like to thank Father A.G. Luhur Prihadi, $\operatorname{Pr}$ as leader of the Semarang Cathedral, and Father R.D. Tukiyo as the leader of the Bogor Cathedral for permitting us to do this research in the amazing buildings. Our gratitude would be addressed to both Cathedral staff for helping us to research inside the Cathedral.

\section{REFERENCES}

[1] S. Zhang and Z. Lin, "Predicted Mean Vote with skin temperature from standard effective temperature model," Build. Environ., vol. 183, no. July, p. 107133, 2020, DOI: 10.1016/j.buildenv.2020.107133.

[2] S. Yuliani, G. Hardiman, and E. Setyowati, "Green-roof: The role of community in the substitution of green-space toward sustainable development," Sustain., vol. 12, no. 4, 2020, DOI: $10.3390 /$ su12041429.

[3] E. Setyowati, S. B. Pribadi, S. A. K. Aidon Uda, T. R. Debby, and B. I. R. Harsritanto, "The planning and design of kampong Pakuncen in Yogyakarta based on the green concept," J. Archit. Urban., vol. 43, no. 1, pp. 21-35, 2019, DOI: $10.3846 /$ jau.2019.6123.

[4] E. Setyowati and E. E. Pandelaki, "The concept of sustainable prefab modular housing made of natural fiber reinforced polymer (NFRP)," IOP Conf. Ser. Mater. Sci. Eng., vol. 316, no. 1, 2018, DOI: 10.1088/1757-899X/316/1/012004.

[5] A. Aflaki, N. Mahyuddin, Z. Al-Cheikh Mahmoud, and M. R. Baharum, "A review on natural ventilation applications through building façade components and ventilation openings in tropical climates," Energy Build., vol. 101, pp. 153-162, 2015, DOI: 10.1016/j.enbuild.2015.04.033.

[6] S. S. Y. Lau, J. Zhang, and Y. Tao, "A comparative study of thermal comfort in learning spaces using three different ventilation strategies on a tropical university campus," Build.
Environ., vol. 148, no. August 2018, pp. 579-599, 2019, DOI: 10.1016/j.buildenv.2018.11.032.

[7] M. V. Cruz-Salas, J. A. Castillo, and G. Huelsz, "Effect of windexchanger duct cross-section area and geometry on the room airflow distribution," J. Wind Eng. Ind. Aerodyn., vol. 179, no. March, pp. 514-523, 2018, DOI: 10.1016/j.jweia.2018.06.022.

[8] J. Park, X. Sun, J. Il Choi, and G. H. Rhee, "Effect of wind and buoyancy interaction on single-sided ventilation in a building," J. Wind Eng. Ind. Aerodyn., vol. 171, no. October, pp. 380-389, 2017, DOI: 10.1016/j.jweia.2017.10.016.

[9] F. Azizpour, S. Moghimi, E. Salleh, S. Mat, C. H. Lim, and K. Sopian, "Thermal comfort assessment of large-scale hospitals in tropical climates: A case study of University Kebangsaan Malaysia Medical Centre (UKMMC)," Energy Build., vol. 64, pp. 317-322, 2013, DOI: 10.1016/j.enbuild.2013.05.033.

[10] Q. Duan and J. Wang, "Thermal Conditions Controlled by Thermostats: An Occupational Comfort and Well-being Perspective," Civil Engineering and Architecture, vol. 5, no. 5, pp. 173-179, 2017, DOI: 10.13189/cea.2017.050502.

[11] S. V Szokolay, "Climate analysis based on the psychrometric chart," Int. J. Ambient Energy, vol. 7, no. 4, pp. 171-182, Oct. 1986, DOIi: 10.1080/01430750.1986.967 5499.

[12] ANSI/ASHRAE, "ANSI/ASHRAE Standard 55-2017: Thermal Environmental Conditions for Human Occupancy," ASHRAE Inc., vol. 2017, p. 66, 2017, DOI: ISSN 1041-2336.

[13] F. Azizpour, S. Moghimi, S. Mat, C. H. Lim, and K. Sopian, "Objective and Subjective Assessments of Thermal Comfort in Hot-Humid Region," Recent Res. Chem. Biol. Environ. Cult., pp. 207-210, 2012.

[14] F. Z. Çağlar, G. Z. Gedik, and H. Gökdemir, "The impact of transparency ratio on thermal comfort: A field study on educational building," Civil Engineering and Architecture, vol. 8, no. 5, pp. 890-897, 2020, DOI: 10.13189/cea.2020.080516.

[15] Y. Xia, W. Lin, W. Gao, T. Liu, Q. Li, and A. Li "Experimental and numerical studies on indoor thermal comfort in fluid flow: A case study on primary school classrooms," Case Stud. Therm. Eng., vol. 19, no. December 2019, p. 100619, 2020, DOI: 10.1016/j.csite.2020.100619.

[16] A. Martínez-Molina, I. Tort-Ausina, S. Cho, and J. L. Vivancos, "Energy efficiency and thermal comfort in historic buildings: A review," Renew. Sustain. Energy Rev., vol. 61, pp. 70-85, 2016, DOI: 10.1016/j.rser.2016.03.018.

[17] E. Dewiyana, N. Ibrahim, and N. H. Hajar, "The Green Aspects of Adaptive Reuse of Hotel Penaga," Procedia - Soc. Behav. Sci., vol. 222, pp. 631-643, 2016, DOI: 10.1016/j.sbspro.2016.05.220.

[18] H. F. S. Rusyda, E. Setyowati, and G. Hardiman, "Thermal condition of Semarang heritage Tawang railways station," AIP Conf. Proc., vol. 2114, no. June, 2019, DOI: $10.1063 / 1.5112446$.

[19] B. Y. A. Wastunimpuna, W. S. Budi, and E. Setyowati, "The Effect of Outside Corridor's Orientation to Interior Thermal Condition at Lawang Sewu Semarang.," E3S Web Conf., vol. 
73, 2018, DOI: 10.1051/e3sconf/20187301011.

[20] S. I. U. H. Gilani, M. H. Khan, and W. Pao, "Thermal Comfort Analysis of PMV Model Prediction in Air Conditioned and Naturally Ventilated Buildings," Energy Procedia, vol. 75, pp. 1373-1379, 2015, DOI: 10.1016/j.egypro.2015.07.218.

[21] A. García, F. Olivieri, E. Larrumbide, and P. Ávila, "Thermal comfort assessment in naturally ventilated offices located in a cold tropical climate, Bogotá," Build. Environ., vol. 158, no. April, pp. 237-247, 2019, DOI: 10.1016/j.buildenv.2019.05.013.

[22] J. Gao, Y. Wang, and P. Wargocki, "Comparative analysis of modified PMV models and SET models to predict human thermal sensation in naturally ventilated buildings," Build. Environ., vol. 92, pp. 200-208, 2015, DOI: 10.1016/j.buildenv.2015.04.030.

[23] A. Sekatia, E. Setyowati, G. Hardiman, and B. Harsritanto, "The Effect of Low Ventilation to Thermal Condition in Cathedral Church," Feb. 2019, pp. 1-10, DOI: 10.2991/senvar-18.2019.1.

[24] World Bank Group, "Indonesia Climate Data," 2020, https://climateknowledgeportal.worldbank.org/country/indo nesia/climate-data-historical\#: :text $=$ Climate Data Historical,high of $30.2^{\circ} \mathrm{C}$. (accessed Sep. 01, 2020).

[25] A. Sekatia, E. Setyowati, and G. Hardiman, "The Effectivity of Down Ventilation Towards Thermal Comfort and PMV ( Predicted Mean Vote ) in Cathedral Church, Semarang," vol. 15 , pp. 39-52, 2015.

[26] A. Sekatia, E. Setyowati, and G. Hardiman, "Thermal condition of passive cooling system in Bogor Cathedral Church," IOP Conf. Ser. Earth Environ. Sci, vol. 213, p. 12044, 2018, DOI: 10.1088/1755-1315/213/1/012044.

[27] BPS Central Jawa Province, "Height Above Mean Sea Level (AMSL) by Regency/Municipality in Jawa Tengah Province, 2015 -2018," 2019.https://jateng.bps.go.id/statictable/2017/ 10/26/1513/tinggi-wilayah-di-atas-permukaan-laut-dpl-men urut-kabupaten-kota-di-provinsi-jawa-tengah-2015---2018. html (accessed Sep. 01, 2020).

[28] B. C. Government, "Letak Geografis Kota Bogor,” 2016. https://kotabogor.go.id/index.php/page/detail/9/letak-geogra fis.

[29] ISO, "ISO-7726 1998." Ergonomics of the thermal environment - Instruments for measuring physical quantities, 1998 .

[30] G. S. Brager and R. J. De Dear, "Thermal adaptation in the built environment: A literature review," Energy Build., vol. 27, no. 1, pp. 83-96, Feb. 1998, DOI: 10.1016/s0378-7788( 97)00053-4.

[31] T. Hoyt et al., "CBE Thermal Comfort Tool." Center for the Built Environment, University of California Berkeley, 2019, [Online]. Available: https://comfort.cbe.berkeley.edu/.

[32] O. H. Koenigsberger, O. H, and T. G, Manual Of Tropical Housing \& Building. Orient Longman Private Limited, 1975. 